\title{
PENGARUH KINERJA PEMDA, KARAKTERISTIK PEMDA, DAN KARAKTERISTIK DEMOGRAFI TERHADAP IMPLEMENTASI $E$ - GOVERNMENT \\ (Studi Pada Pemerintah Daerah Tingkat Provinsi \\ di Indonesia)
}

\author{
Bambang \\ Jurusan Akuntansi FEB Unram \\ bambang@unram.ac.id \\ Herlina Pusparini \\ Jurusan Akuntansi FEB Unram \\ h.pusparini@unram.ac.id \\ Nurabiah \\ Jurusan Akuntansi FEB Unram \\ nurabiah@unram.ac.id
}

\begin{abstract}
The real manifestation of e-government applications that have been commonly implemented and copied is the creation of local government web sites. The local government website is one of the strategies in implementing systematic e-government development through realistic and measurable stages. The community website is the first country in the development of e-government in Indonesia which has a goal so that the Indonesian people can easily access information and services, including in the development of democracy in Indonesia using internet media. This study aims to integrate the performance of regional governments towards the implementation of egovernment, changes between government and government, and the demographics of regional governments towards the implementation of egovernment.

The population in this study is the provincial government in Indonesia. The sample in this study was chosen based on criteria. The criteria are provincial level local governments included in the PeGi index during 2014 - 2015. The data used in this study are secondary data. The method of data analysis uses SmartPLS version 3.2.6. The results of this study indicate that the performance of regional governments influences the implementation of e-government while the characteristics of regional governments and demographic characteristics do not influence the implementation of e-government.

Keywords: performance, characteristics, demography, local government, e-government
\end{abstract}




\begin{abstract}
Abstrak
Wujud nyata dari aplikasi e-government yang telah umum dilaksanakan dan diatur pelaksanaannya adalah pembuatan situs web pemerintah daerah. Situs web pemerintah daerah merupakan salah satu strategi didalam melaksanakan pengembangan e-government secara sistematik melalui tahapan yang realistik dan terukur. Situs web pemerintah daerah merupakan tingkat pertama dalam pengembangan e-government di Indonesia yang memiliki sasaran agar masyarakat Indonesia dapat dengan mudah memperoleh akses kepada informasi dan layanan pemerintah daerah, serta ikut berpartisipasi di dalam pengembangan demokrasi di Indonesia dengan menggunakan media internet. Penelitian ini bertujuan untuk menguji secara empiris pengaruh kinerja pemda terhadap implementasi e-government, pengaruh karakteristik pemda terhadap implementasi e-government, dan pengaruh karakteristik demografi pemda terhadap implementasi e-government.

Populasi dalam penelitian ini adalah pemerintah provinsi di Indonesia. Adapun sampel dalam penelitian ini dipilih berdasarkan kriteria. Kriterianya adalah pemerintah daerah tingkat provinsi yang masuk dalam indeks PeGi selama tahun 2014 - 2015. Sumber data yang digunakan dalam penelitian ini adalah data sekunder. Metode analisis data menggunakan SmartPLS versi 3.2.6. Hasil penelitian ini menunjukkan bahwa kinerja pemda berpengaruh terhadap implementasi e-goverment sedangkan karakteristik pemda dan karakteristik demografi tidak berpengaruh terhadap implementasi e-government.

\section{Kata Kunci: kinerja, karakteristik, demografi, pemda, e- government}

\title{
PENDAHULUAN
}

E-Government merupakan penggunaan teknologi informasi oleh badan pemerintahan untuk menjalankan kegiatan pemerintahan. $E$ Government diterapkan di Indonesia untuk menunjang kinerja dalam sebuah pemerintahan, dan dalam menjalankan E-Government memiliki sebuah kendala dalam pengembangannya agar dapat membuat $E$ government lebih efisien dan efektif untuk kalangan pemerintahan. Perkembangan e-Government di Indonesia telah mampu membuktikan kepada masyarakat bahwa pemanfaatan teknologi informasi memiliki peran yang cukup vital dalam penerapan pemerintahan memilki akuntabilitas dan transparansi dalam berbagai segi. Tahun 2003 menjadi tonggak baru dalam implementasi e-Government di Indonesia. Melalui Instruksi Persiden No.3 Tahun 2003 tentang kebijakan dan strategi Nasional Pengembangan $e-$ Government, sejumlah instansi pemerintah mulai menggeliat. Belum lagi Kementrian Komunikasi dan Informatika yang pada tahun 2003 juga 
membuat turunan dari inpres No.3 Tahun 2003, melalui Kepmen No.55 Tahun 2003 tentang panduan pembangunan infrastuktur portal pemerintah. Saat itu, portal memang masih menjadi pintu gerbang pertama menuju keterbukaan informasi tentang pembangunan. Sehingga, banyak institusi pemerintah ramai- ramai bikin situs yang menyediakan informasi seputar pemerintahan, walaupun hingga saat ini belum banyak situs pemerintahan yang dapat memberikan informasi yang up to date.

Lima tahun semenjak Inpres tersebut di sahkan, perubahan demi perubahan mulai tercipta. Instansi pemerintah seakan berlomba-lomba menciptakan pelayanan publik yang efektif dan efisien. Tercatat, beberapa instansi pemerintah dari level departemen hingga kabupaten/Kota mulai menggunakan TI sebagai alat yang memudahkan mereka dalam bekerja sesuai kebutuhan dan tujuan pembangunan yang telah mereka rencanakan. Walaupun Penerapan e-Government (e-gov) sudah menjadi kebutuhan dalam organisasi publik saat ini. Namun, di Indonesia masih banyak organisasi publik belum maksimal dalam penerapan e-gov.

Hal ini terlihat dari hasil publikasi yang dilakukan oleh PBB tentang peringkat EGDI (E-Government Development Index) berdasarkan survei tahun 2016 menyatakan bahwa Indonesia mendapat peringkat ke 116 EGDI, turun 10 peringkat dibandingkan tahun 2014 yang menduduki peringkat ke 106. Kondisi ini masih jauh berada di bawah negara-negara di Asia Tenggara seperti Malaysia (peringkat ke-60), Filipina (peringkat ke-71), dan Brunei Darussalam (peringkat ke-83). Di samping itu terlihat dari nilai Online Service Index (OSI) dan Telecommunication Infrastructure Index (TII) Indonesia juga masih berada di bawah rata-rata di regional Asia Tenggara. Indonesia berada pada angka 0,3623 OSI dan 0,3016 TII, sedangkan rata OSI di kawasan Asia Tenggara adalah 0,4598 dan 0,306 pada angka TII. Tetapi dari segi Human Capital Index (HCI) Indonesia sudah mampu melebihi nilai rata-rata regional Asia Tenggara $(0,6233)$ yaitu pada angka 0,6796.

Hal ini tentunya menjadikan suatu tantangan tersendiri bagi kita untuk dapat meningkatkan peringkat EGDI di tahun-tahun yang akan datang, di mana angka yang diperoleh merupakan cermin dari kondisi penerapan EGoverment untuk memastikan bahwa lembaga-lembaga publik apakah sudah lebih inklusif, efektif, akuntabel dan transparan. Oleh karena itu, pemerintah dituntut mampu memberikan informasi secara komprehensif kepada masyarakat. Masyarakat semakin menyadari kebutuhan akan transparansi dan akuntabilitas akan informasi keuangan pemerintah. Mengacu pada teori agensi (agency theory), akuntabilitas publik dapat dimaknai dengan adanya kewajiban pihak pemegang amanah (agent) untuk memberikan pertanggungjawaban, menyajikan, melaporkan, dan mengungkapkan segala aktivitas dan kegiatan yang menjadi tanggung jawabnya kepada pihak pemberi amanah (principal) yang memiliki hak dan 
kewenangan untuk meminta pertanggungjawaban tersebut (Haryanto dan Sahmuddin 2007).

Hal tersebut juga dibutuhkan agar tidak terjadi kesalahpahaman masyarakat akan pertanggungjawaban pengelolaan dana APBD oleh pemerintah yang terkadang menimbulkan dugaan-dugaan negatif yang dapat menempatkan pemerintah pada posisi yang serba salah. Dengan demikian, demokratisasi dapat ditegakkan dengan baik. Tujuan penting dalam implementasi e-government adalah mewujudkan transparansi dan akuntabilitas publik yang lebih baik dari sebelumnya. Hal ini dapat dicapai dengan adanya fasilitas teknologi informasi yang memadai dan tenaga yang ahli dalam mengerjakannya. Pengadopsian teknologi informasi dan komunikasi mengubah cara berinteraksi antara sebuah lembaga dengan lembaga lainnya. Faktanya, penggunaan teknologi informasi dan komunikasi pada pemerintahan mengubah cara masyarakat berinteraksi dengan pemerintah dan cara pemerintah mengelola tugas dan pekerjaannya sehari-hari. Implementasi e-government diharapkan oleh masyarakat dan pemerintah sebagai cara untuk meningkatkan transparansi, akuntabilitas dan efisiensi kinerja (Chun et al. 2012).

Wujud nyata dari aplikasi e-government yang telah umum dilaksanakan dan diatur pelaksanaannya adalah pembuatan situs web pemerintah daerah. Situs web pemerintah daerah merupakan salah satu strategi didalam melaksanakan pengembangan e-government secara sistematik melalui tahapan yang realistik dan terukur. Situs web pemerintah daerah merupakan tingkat pertama dalam pengembangan $e-$ Government di Indonesia yang memiliki sasaran agar masyarakat Indonesia dapat dengan mudah memperoleh akses kepada informasi dan layanan pemerintah daerah, serta ikut berpartisipasi di dalam pengembangan demokrasi di Indonesia dengan menggunakan media internet (Buku panduan Kominfo, 2002, 3)

Penelitian mengenai faktor-faktor yang mempengaruhi implementasi e-government menjadi topik penelitian yang menarik. Hal ini didasarkan bahwa pada hasil penelitian terdahulu yang tidak konsisten baik pada faktor non-keuangan maupun faktor keuangan pemerintah daerah. Hasil penelitian mengenai pengaruh faktor non-keuangan, misalnya Martani (2010) menemukan bahwa variabel tipe pemerintah daerah hasilnya tidak berpengaruh signifikan. Selain itu faktor keuangan seperti pendapatan asli daerah (PAD) juga menunjukkan hasil yang tidak konsisten di mana penelitian dan Martani (2010) menemukan bahwa variabel pendapatan asli daerah (PAD) berpengaruh signifikan. Sebaliknya penelitian Adhi dan Suhardi (2010) menemukan bahwa implementasi e-government tidak memiliki pengaruh yang signifikan. Selain hasil pengukuran variabel yang tidak konsisten, penelitian ini memiliki perbedaan dengan penelitian sebelumnya yaitu penelitian ini menggunakan indeks pemeringkatan $e$ government (PeGI) yang dikeluarkan oleh Kementerian Komunikasi dan 
Informasi. Informasi yang digunakan dalam penelitian ini lebih formal dikeluarkan oleh kementerian teknis terkait sehingga lebih valid dibanding dengan ukuran dari penelitian sebelumnya. Adapun pembaruan penelitian pada penelitian ini dibandingkan dengan penelitian sebelumnya yaitu pada penelitian ini menggabungkan beberapa variabel yang mempengaruhi implementasi e-government dan penelitian ini menguji dengan pendekatan model struktural sehingga bisa merefleksikan konstruk yang diuji melalui indikator-indikator secara lebih komprehensif yaitu dengan menggunakan PLS.

Atas dasar hal tersebut, maka penelitian ini bertujuan untuk menguji secara empiris: pengaruh kinerja pemda, karakteristik pemda, dan karakteristik demografi terhadap implementasi e-government. Dengan harapan bagi pembuat keputusan di sector publik dapat digunakan sebagai bahan informasi dan pertimbangan dalam membuat kebijakan di masa depan dengan adanya faktor-faktor pendorong implementasi e-government setiap provinsi.

\section{TELAAH LITERATUR DAN PENGEMBANGAN HIPOTESIS}

\section{Teori Keagenan (Agency Theory)}

Teori Keagenan (Agency Theory) melibatkan hubungan kontraktual antara dua pihak, yaitu prinsipal dan agen. Teori ini berakar dari sinergi teori ekonomi, teori keputusan, sosiologi, dan teori organisasi. Teori Keagenan menganalisis susunan kontraktual diantara dua atau lebih individu, kelompok, atau organisasi. Mardiasmo (2002) menjelaskan bahwa pengertian akuntabilitas sebagai kewajiban pemegang amanah (pemerintah) untuk memberikan pertanggungjawaban, menyajikan, melaporkan, dan mengungkapkan segala aktivitas dan kegiatan yang menjadi tanggungjawabnya kepada pihak pemberi amanah (masyarakat) yang memiliki hak untuk meminta pertanggungjawaban tersebut. Pendapat Mardiasmo mengenai akuntabilitas tersebut mengandung arti bahwa terdapat hubungan keagenan antara masyarakat sebagai prinsipal dan pemerintah sebagai agen. Oleh karena itu, mengingat pentingnya akuntabilitas terhadap publik tersebut, perlu dilakukan revitalisasi $e$ government yang dapat meningkatkan akuntabilitas dan transparansi kinerja pemerintah demi kepentingan kesejahteraan masyarakat luas. 


\section{Kerangka Konseptual Penelitian}

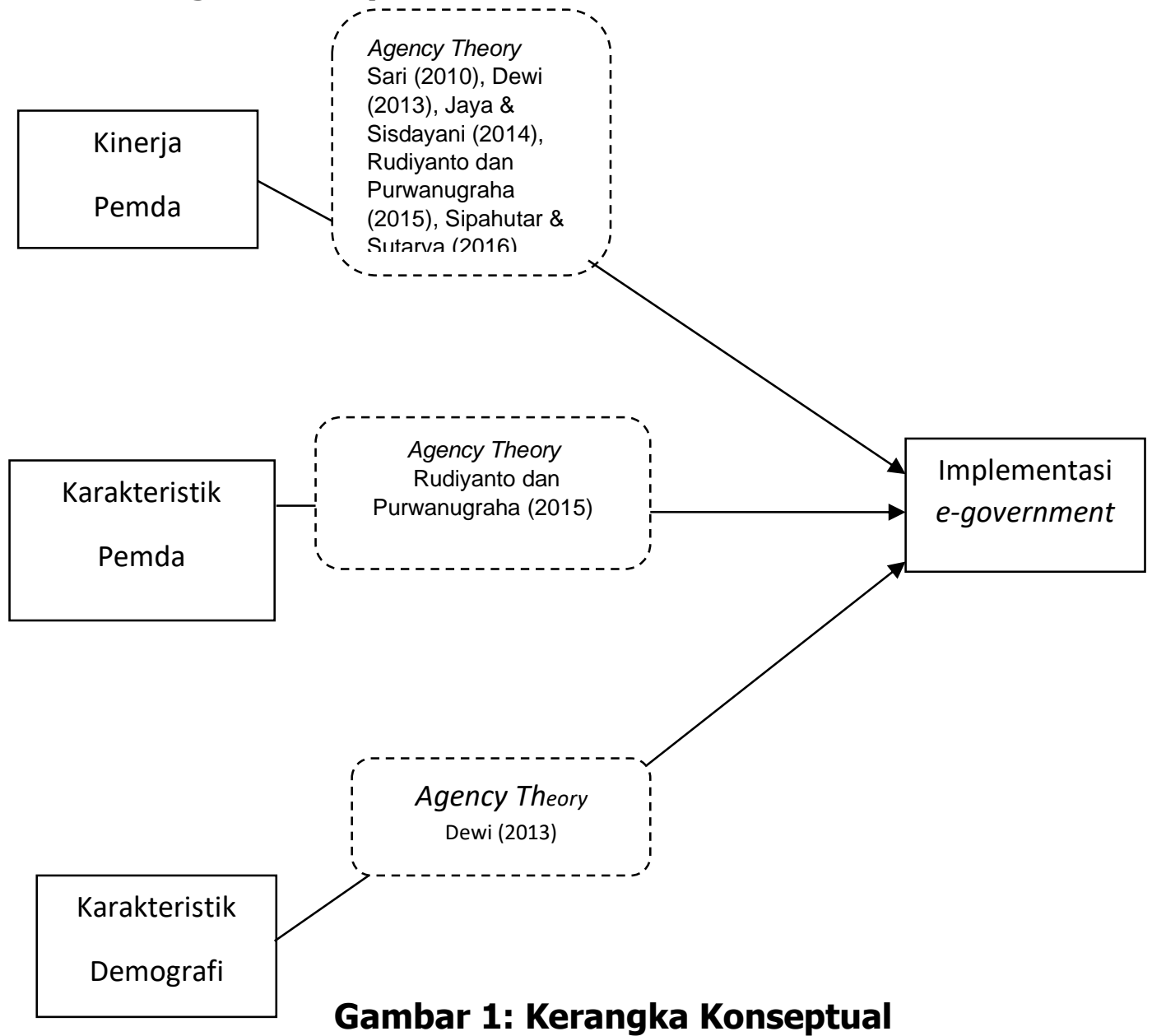

\section{Hipotesis Penelitian}

Pengaruh kinerja pemda terhadap implementasi e-government

Berdasarkan Undang-Undang No.33 Tahun 2004 tentang Perimbangan keuangan antara pemerintah Pusat dan Daerah, pendapatan asli daerah (PAD) didefinisikan sebagai pendapatan yang diperoleh daerah yang dipungut berdasarkan peraturan daerah sesuai dengan peraturan perundang-undangan. Implementasi desentralisasi fiskal yang bertolak ukuran dari pendapat asli daerah harus diupayakan secara optimal karena pemerintah daerah tidak dapat melaksanakan fungsinya dengan efektif dan efisien tanpa biaya yang cukup untuk membiayai pelayanan dan pembangunan yang dilakukan pemerintah daerah. Kim (2007) menyatakan bahwa kinerja e-government ditentukan oleh kesejahteraan ekonomi, pendidikan, urbanisasi, kebebasan rakyat, efektivitas pemerintahan, dan interaksi antara penggunaan internet dan kesejahteraan ekonomi Hal ini dapat diartikan bahwa jika kesejahteraan ekonomi daerah tinggi, maka pemerintah daerah mempunyai biaya yang cukup untuk melayani 
masyarakatnya melalui implementasi e-government, karena implementasi e-government diharapkan untuk menyediakan pelayanan kepada masyarakat yang membutuhkan biaya besar.

Pendapatan asli daerah menunjukkan efektifitas pemerintah daerah dalam mengelola potesi daerah untuk dijadikan sebagai pendapatan secara otonomi yang digunakan untuk kesejahteraan masyarakat. Pendapatan asli daerah memiliki tingkat material yang membuat pemerintah daerah lebih memilih untuk membatasi akses informasi mengenai pendapatan asli daerah kepada masyarakat (Craven \& Marston 1999). Penelitian sebelumnya yang dilakukan oleh Medina (2012) menyatakan bahwa pendapatan asli daerah memiliki pengaruh positif terhadap transparansi informasi keuangan pada website pemerintah daerah tersebut. Kesimpulan yang sama juga dikemukakan oleh Laswad et.al. (2005) yang menyatakan bahwa kinerja pemerintah daerah berdasarkan pendapatan asli daerah memiliki pengaruh positif terhadap pengungkapan informasi keuangan melalui website pemerintah daerah itu sendiri.

UU Nomor 33 Tahun 2004 mendefinisikan Dana Alokasi Umum adalah dana yang dialokasikan kepada pemerintah daerah yang bertujuan pemerataan kemampuan keuangan antar daerah. Dana alokasi umum bersifat "Block Grant" yang artinya kepala daerah dapat menggunakan dana alokasi umum sesuai kebutuhan suatu daerah yang diprioritaskan secara bertanggung jawab. Robbin dan Austin (1986) menyatakan bahwa besarnya dana alokasi umum yang diterima menggambarkan tingkat ketergantungan yang dimiliki suatu pemerintah daerah. Liestiani (2008) mengungkapkan bahwa pemerintah yang memiliki tingkat ketergantungan yang tinggi memiliki tekanan dari pemerintah pusat untuk mengungkapkan informasi keuangan daerah lebih lengkap.

Belanja modal merupakan penggunaan dana APBD yang dilakukan pemerintah daerah untuk menambah umur atau jumlah aktiva tetap. Belanja modal digunakan pemerintah daerah untuk meningkatkan pelayanan kepada masyarakat dengan harapan masyarakat memperoleh pelayanan yang ramah dan berkualitas. Sehingga membuat kinerja pemerintah daerah di mata masyarakat menjadi positif. Afryansyah (2013) berpendapat bahwa besarnya belanja modal yang dikeluarkan pemerintah dalam melakukan investasi untuk kesejahteraan masyarakat mempengaruhi tingkat pengungkapan informasi keuangan.

Berdasarkan pemaparan di atas, baik secara teoritis maupun empiris maka hipotesis dalam penelitian ini adalah sebagai berikut:

$\mathrm{H}_{1}$ : kinerja pemda berpengaruh terhadap implementasi e-goverment

\section{Pengaruh karakteristik pemda terhadap implementasi e- government}

Karakteristik berarti mempunyai sifat khas seusai dengan perwatakan tertentu (Syafitri 2012). Lesmana (2010) dalam Syafitri (2012) mengatakan 
bahwa karakteristik pemerintah daerah bersifat khas dari otoritas administratif pemerintah provinsi dan pemerintah kabupaten/kota. Elemenelemen yang terdapat dalam laporan keuangan pemerintah daerah dapat menggambarkan karakteristik pemerintah daerah. Laporan keuangan merupakan suatu alat yang memfasilitasi transparansi akuntabiitas publik, yang menyediakan informasi yang relevan mengenai kegiatan operasionalnya, posisi keuangan, arus kas, dan penjelasan atas pos-pos yang ada di dalam laporan keuangan tersebut.

Menurut UU No. 32 Tahun 2004, belanja daerah adalah semua kewajiban daerah yang diakui sebagai pengurang nilai kekayaan bersih dalam periode anggaran yang bersangkutan. Belanja daerah diprioritaskan untuk melindungi dan meningkatkan kualitas kehidupan masyarakat dalam upaya memenuhi kewajiban daerah. Dan Berdasarkan Pasal 28 Ayat 2 UU No. 33 Tahun 2004, jumlah penduduk mencerminkan kebutuhan akan penyediaan layanan publik setiap daerah. Semakin besar jumlah penduduk suatu daerah maka diikuti dengan penyediaan layanan publik yang semakin besar pula, dalam hal ini pemerintah daerah dituntut untuk mengungkapkan segala sesuatu informasi mengenai daerahnya kepada masyarakat.

Berdasarkan pemaparan di atas, baik secara teoritis maupun empiris maka hipotesis dalam penelitian ini adalah sebagai berikut:

$\mathrm{H}_{2}$ : Karakteristik pemda berpengaruh terhadap implementasi $e$ government

\section{Pengaruh karakteristik demografi terhadap implementasi e- government}

Garcia-Sanchez et al. (2013) meneliti hubungan tingkat pengangguran terhadap pengungkapan informasi non keuangan pada website Pemda. Dalam penelitiannya Garcia-Sanchez dijelaskan bahwa daerah yang mengalami perkembangan ekonomi yang tinggi, cenderung juga akan mengalami ekspansi pelayanan pada sektor publik. Ekspansi jasa yang dilakukan dapat menjadikan bertambahnya stakeholder yang terangkul, sehingga pemerintah cenderung juga akan mengungkapkan informasi yang lebih banyak.

Navarro et al. (2011) menemukan bahwa terdapat hubungan positif antara tingkat pengangguran dengan tingkat pengungkapan. Sementara itu Guillamo et al. (2011) menemukan hasil sebaliknya yaitu hubungan negatif antara tingkat pengangguran dengan tingkat pengungkapan. Sementara itu Garcia-Sanchez et al. (2013) tidak menemukan hasil yang signifikan dalam penelitiannya. Penelitian di Indonesia oleh Martani et al (2013) juga tidak ditemukan hasil yang signifikan.

Style dan Tennyson (2007) menyatakan bahwa pendapatan perkapita yang semakin tinggi akan mengakibatkan political monitoring yang semakin tinggi pula oleh masyarakatnya sehingga tekanan untuk menyediakan informasi kepada publik semakin lebih besar. Stlye and Tennyson (2007) 
dan Serrano et al (2008) menemukan korelasi positif antara tingkat pendapatan perkapita dengan tingkat pengungkapan informasi pada website. Martani et al. (2013) menemukan hubungan positif yang signifikan antara tingkat kesejahteraan penduduk dengan tingkat pengungkapan informasi keuangan pada website Pemda. Penelitian yang melihat hubungan tingkat kesejahteraan penduduk dengan pengungkapan informasi non keuangan pada website pemda belum pernah dilakukan. Namun tekanan permintaan informasi yang daerah yang memiliki penduduk dengan kesejahteraan yang tinggi umumnya tidak hanya terbatas pada informasi keuangan. Informasi non keuangan, khususnya pelayanan publik yang dilakukan Pemda akan banyak diminta oleh penduduk dengan kesejahteraan tinggi sehingga tekanan untuk mengungkapkan informasi ini semakin besar.

Salah satu indikator yang dapat digunakan untuk mengukur tingkat kesejahteraan penduduk adalah pendapatan perkapita daerah. Tingkat kesejahteraan yang tinggi mendorong masyarakat lebih peduli terhadap pelaksanaan pemerintahan sehingga mendorong Pemda untuk melakukan pengungkapan informasi yang lebih besar. Adanya ketidakkonsistensian pada hasil penelitian sebelumnya menjadikan penulis tidak menyatakan arah dalam hipotesis ini.

Berdasarkan pemaparan di atas, baik secara teoritis maupun empiris maka hipotesis dalam penelitian ini adalah sebagai berikut:

\section{$\mathrm{H}_{3}$ : Karakteristik demografi berpengaruh terhadap implementasi e-government}

\section{METODE PENELITIAN}

\section{Jenis Penelitian}

Jenis penelitian ini adalah eksplanatory. Penelitian eksplanatori (explanatory research) adalah untuk menguji hipotesis antar variabel yang dihipotesiskan. Hipotesis itu sendiri menggambarkan hubungan antara dua variabel, untuk mengetahui apakah suatu variabel berasosiasi ataukah tidak dengan variabel lainnya, atau apakah variabel disebabkan atau dipengaruhi atau tidak oleh variabel lainnya (Sugiyono 2011:21).

\section{Teknik Pengumpulan Data}

Teknik pengumpulan data yang digunakan dalam penelitian ini adalah teknik dokumentasi. Teknik dokumentasi adalah teknik pengumpulan data dengan mendapatkan data melalui observasi dengan internet terhadap ketersediaan E-Government provinsi di Indonesia dan juga berasal dari berbagai website di internet, seperti BPS, Direktorat Jenderal Keuangan Daerah, Kementrian Dalam Negeri, Kemeninfo dan berbagai website pemerintah. 


\section{Populasi dan Sampel}

Populasi dalam penelitian ini adalah pemerintah provinsi di Indonesia. Sampel adalah suatu porsi atau bagian dari populasi tertentu yang menjadi perhatian (Mason dan Douglas 2000). Sampel penelitian diambil secara purposive sampling yaitu metode pemilihan sampel pada karakteristik populasi yang sudah diketahui sebelumnya. Adapun sampel dalam penelitian ini dipilih berdasarkan kriteria. Kriterianya adalah pemerintah daerah tingkat provinsi yang masuk dalam indeks PeGi selama tahun $2014-2015$.

\section{Variabel Penelitian}

Berdasarkan pada pokok permasalahan dan hipotesis yang telah dirumuskan, maka variabel-variabel yang dianalisis dalam penelitian ini adalah:

1. Variabel eksogen dalam penelitian ini adalah kinerja pemda, karakteristik pemda, dan karakteristik demografi

2. Variabel endogen dalam penelitian ini adalah implementasi $e$ government.

Instrumen Penelitian

\section{Tabel 1. Variabel dan Indikator Penelitian}

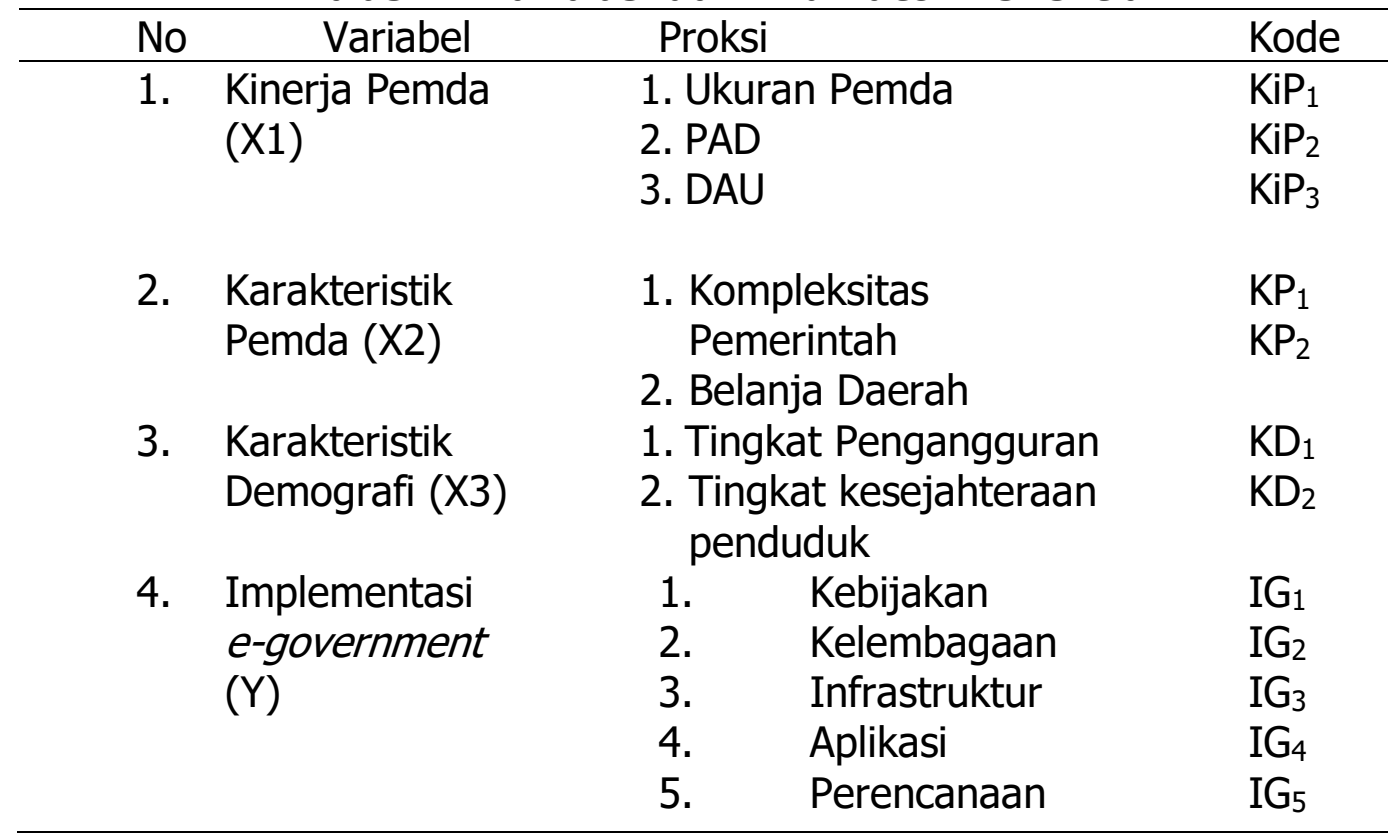

Sumber: diolah dari berbagai sumber, 2017.

\section{Analisis Data}

Penelitian ini menggunakan metode analisis data dengan menggunakan software SmartPLS versi 3.2.1.m3 yang dijalankan dengan media computer, terdapat beberapa langakah dalam menyusun model PLS : 1) Merancang inner model. 2) Merancang outer model. 3) Merekontruksi diagram jalur. 4) Merekontruksi diagram jalur ke persamaan. 5) Estimasi 
koefisien jalur dan nilai loading. 6) Evaluasi goodness of fit. 7) Pengujian hipotesis.

\section{HASIL PENELITIAN DAN PEMBAHASAN}

\section{Uji Validitas}

\section{Convergent Validity}

Convergent validity dalam PLS dengan indikator reflektif dinilai berdasarkan loading factor (korelasi antara skor item/skor komponen dengan skor konstruk) indikator-indikator yang mengukur konstruk tersebut. Rule of thumb yang biasanya digunakan untuk mengukur validitas konvergen adalah outer loading $>0,7$, namun menurut Chin (1998) nilai loading factor 0,5 - 0,6 masih dianggap cukup (Ghozali,2015:74). Nilai loading factor dalam penelitian ini ditunjukkan dalam tabel 2 sebagai berikut:

Tabel 2. Loading Factor

\begin{tabular}{|c|c|c|c|c|c|}
\hline & $\begin{array}{l}\text { Implementasi } \\
\text { e-goverment }\end{array}$ & $\begin{array}{c}\text { Karakteristik } \\
\text { Demografi }\end{array}$ & $\begin{array}{c}\text { Karakteristik } \\
\text { Pemda }\end{array}$ & $\begin{array}{l}\text { Kinerja } \\
\text { Pemda }\end{array}$ & Keputusan \\
\hline IG1 & 0.809 & & & & Valid \\
\hline IG2 & 0.812 & & & & Valid \\
\hline IG3 & 0.442 & & & & Tidak Valid \\
\hline IG4 & 0.461 & & & & Tidak Valid \\
\hline IG5 & 0.755 & & & & Valid \\
\hline KD1 & & -0.306 & & & Tidak Valid \\
\hline KD2 & & 0.838 & & & Valid \\
\hline KP1 & & & 0.985 & & Valid \\
\hline KP2 & & & 0.016 & & Tidak Valid \\
\hline Ki1P & & & & 0.740 & Valid \\
\hline Ki2P & & & & -0.747 & Tidak Valid \\
\hline КіЗр & & & & 0.708 & Valid \\
\hline
\end{tabular}

Sumber: Hasil olahan data 2018

Berdasarkan tabel 2, sebagai kriteria pengujian convergen validity, terlihat dengan jelas indikator - indikator yang memiliki nilai di atas dan di bawah $0,5-0,7$, sehingga indikator - indikator dalam variabel - variabel tersebut yang memiliki nilai loading di bawah 0,5 perlu dieliminasi. Berikut model penelitian setelah eliminasi indikator: 


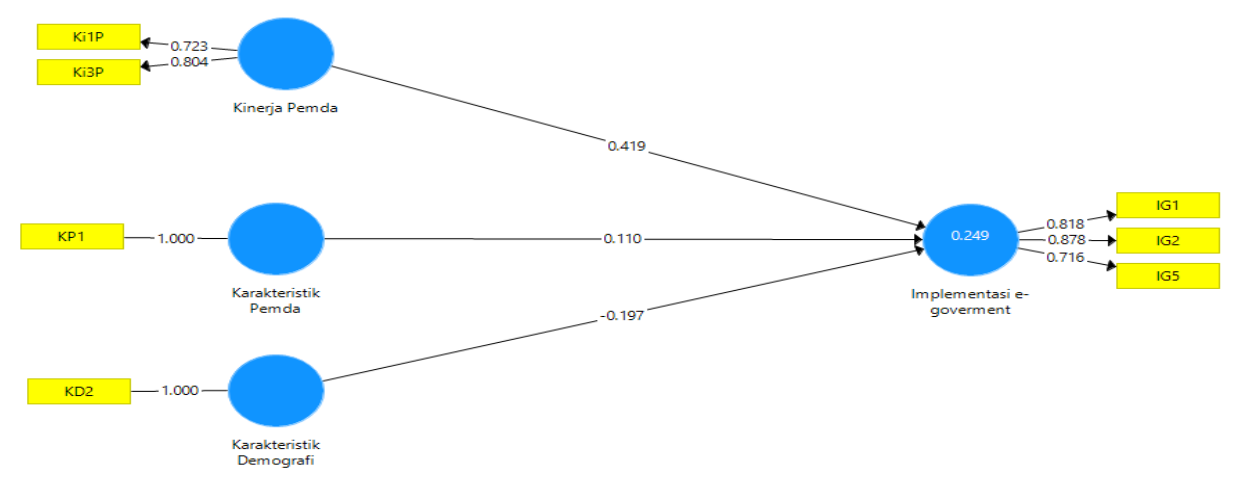

Gambar 2. Model Struktural

Sumber: Data diolah 2018

\section{Discriminant Validity}

Untuk discriminant validity setiap indikator diuji dengan cross loading, pada tabel 3, pengujian discriminant validity digunakan untuk melihat bahwa masing-masing indikator di suatu konstruk akan berbeda dengan indikator di konstruk lain dan mengumpul pada konstruk yang dimaksud.

\begin{tabular}{|c|c|c|c|c|}
\hline & \multicolumn{4}{|c|}{ Implementasi Karakteristik Karakteristik Kinerja } \\
\hline & e-goverment & Demografi & Pemda & Pemda \\
\hline IG1 & 0.818 & -0.005 & 0.362 & 0.398 \\
\hline IG2 & 0.878 & -0.111 & 0.218 & 0.454 \\
\hline IG5 & 0.716 & -0.254 & 0.099 & 0.194 \\
\hline KD2 & -0.132 & 1.000 & 0.157 & 0.113 \\
\hline KP1 & 0.294 & 0.157 & 1.000 & 0.511 \\
\hline Ki1P & 0.320 & 0.212 & 0.687 & 0.723 \\
\hline Ki3P & 0.372 & -0.021 & 0.138 & 0.804 \\
\hline
\end{tabular}

Tabel 3. Cross Loading

Sumber: Data diolah 2018

Berdasarkan pada tabel 3 diatas, dapat dilihat bahwa semua indikator memiliki nilai diatas 0,5 sehingga indikator - indikator tersebut dapat diolah lebih lanjut, dan dapat disimpulkan bahwa konstruk telah memiliki convergent validity yang baik. Nilai cross loading juga menunjukkan adanya discriminant validity yang baik oleh karena nilai korelasi indikator lebih tinggi dibandingkan dengan konstruk lainnya. Sebagai ilustrasi loading factor IG1 
sebesar 0,818 lebih tinggi dibandingkan dengan karakteristik demografi ($0,005)$, karakteristik pemda $(0,362)$ dan kinerja pemda $(0,398)$.

\section{Uji Reliabilitas}

Uji reliabilitas dapat dilihat dari nilai Composite reliability dan Cronbach's alpha. Untuk dapat dikatakan suatu konstruk yang reliabel, maka nilai croanbach's alpha harus $>0,6$ dan nilai composite reliability harus $>0,7$. Berikut adalah hasil pengujian untuk Composite reliability dan Cronbach's alpha.

Tabel 4. Composite Reliability

\begin{tabular}{l|c}
\hline \multicolumn{1}{c}{ Konstruk } & Composite Reliability \\
\hline Implementasi e-goverment & 0.847 \\
\hline Karakteristik Demografi & 1.000 \\
Karakteristik Pemda & 1.000 \\
\hline Kinerja Pemda & 0.737 \\
\hline
\end{tabular}

Sumber: Data diolah 2018

Berdasarkan tabel 4, dapat diketahui bahwa seluruh konstruk dinyatakan reliable karena semua konstruk memiliki nilai diatas 0,70. Sehingga dapat dinyatakan bahwa konstruk pada penelitian ini memiliki reliabilitas yang baik.

Tabel 5. Cronbach'Alpha

\begin{tabular}{l|c}
\hline \multicolumn{1}{c}{ Konstruk } & Cronbach's Alpha \\
\hline Implementasi e-goverment & 0.735 \\
\hline Karakteristik Demografi & 1.000 \\
Karakteristik Pemda & 1.000 \\
Kinerja Pemda & 0.291 \\
\hline
\end{tabular}

Sumber: Data diolah 2018

Berdasarkan pada tabel 5, menunjukkan bahwa nilai cronbach's alpha untuk implementasi e-government, karakteristik demografi dan karakteristik pemda sudah berada di atas 0,7 yaitu sebesar 0,735, 1,00 \& 1,000. Sedangkan untuk kinerja pemda, nilai cronbach's alpha berada dibawah 0,7 yaitu sebesar 0,291, meskipun variabel kinerja pemda memiliki nilai dibawah 0,7 untuk cronbach's alpha, bukan berarti dianggap tidak reliabel karena menurut Cooper et al dalam Jogiyanto (2011) bahwa konstruk yang valid sudah pasti merupakan konstruk yang reliabel.

\section{Uji Hipotesis}

Uji hipotesis dilakukan untuk menjawab masalah penelitian yang telah dirumuskan sebelumnya dengan menggunakan software SmartPLS. Langkah selanjutnya setelah melakukan uji convergen validity dan discriminat validity, yaitu melakukan pengujian model struktural (inner 
model). Nilai struktural dapat dilihat melalui hasil estimasi koefisien parameter path dan tingkat signifikannya. Nilai R-Square dapat dilihat pada tabel 6. dibawah ini:

Tabel 6. R-Square

\begin{tabular}{ll}
\hline Konstruk & $\boldsymbol{R}$ Square \\
\hline Implementasi e-goverment & 0.249 \\
\hline
\end{tabular}

Sumber: Data diolah 2018

Berdasarkan tabel 6 , menunjukkan nilai $R$-Square untuk implementasi e-goverment sebesar 0,249 yang dapat diinterpretasikan bahwa implementasi e-goverment dapat dijelaskan oleh variabel konstruk karakteristik demografi, karakteristik pemda, dan kinerja pemda sebesar $24,9 \%$, sedangkan sisanya $75,1 \%$ dijelaskan oleh variabel lain diluar yang diteliti seperti factor utang, jumlah dewan, tingkat pendidikan, kompleksitas pemerintah dan lainnya. Selanjutnya dilakukan $Q$ Square test yang digunakan untuk mengevaluasi predictive relevance dari model. Nilai $Q$ Square lebih besar dari 0 (nol) menunjukkan bahwa model mempunyai predictive relevance, sedangkan nilai $Q$-Square kurang dari 0 (nol) menunjukkan bahwa model kurang memiliki predictive relevance. Nilai $Q$ Square didapatkan dengan memasukkan nilai $R$-Square ke dalam rumus $Q$ Square berikut:

$$
\begin{aligned}
\mathrm{Q}^{2} & =1-\left(1-\mathrm{R}^{2}\right) \\
& =1-(1-0,162) \\
& =0,162
\end{aligned}
$$

Berdasarkan hasi perhitungan yang dilakukan diperoleh nilai $Q$ Square yang sama dengan nilai $R$-Square, sehingga dapat dijelaskan bahwa variabel laten yang digunakan dalam model memiliki relevansi prediksi. Selanjutnya pengujian hipotesis dilakukan dengan uji t untuk menguji apakah variabel eksogen berpengaruh signifikan terhadap variabel endogen. Dalam menguji hipotesis, dasar yang digunakan terdapat pada output result for inner weight berikut ini: 
Tabel 7. Result For Inner Weight

\section{Path Coefficient (Mean, STDEV, T-Values)}

\begin{tabular}{|l|l|l|l|l|l|l|l|} 
& $\begin{array}{l}\text { Original } \\
\text { Sample } \\
\text { (O) }\end{array}$ & $\begin{array}{l}\text { Sample } \\
\text { Mean } \\
\text { (M) }\end{array}$ & $\begin{array}{l}\text { Standard } \\
\text { Deviation } \\
\text { (STDEV) }\end{array}$ & $\begin{array}{l}\text { T Statistik } \\
\text { (IO/STERRI) }\end{array}$ & T-table & H & Ket \\
\hline $\begin{array}{l}\text { Kinerja Pemda } \\
\text { Implementasi e- } \\
\text { goverment }\end{array}$ & -0.197 & -0.160 & 0.235 & 1.783 & 1.69 & H1 & Diterima \\
\hline $\begin{array}{l}\text { Karakteristik } \\
\text { pemda } \\
\text { Implementasi e- } \\
\text { goverment }\end{array}$ & 0.110 & 0.086 & 0.212 & 0.520 & 1.69 & H2 & Ditolak \\
\hline $\begin{array}{l}\text { Karakteristik } \\
\text { Demografi } \\
\text { Implementasi e- } \\
\text { goverment }\end{array}$ & 0.419 & 0.502 & 1.179 & 1.098 & 1.69 & H3 & Ditolak \\
\hline
\end{tabular}

Sumber: Data diolah 2018

Berdasarkan tabel 7, dapat kita lihat bahwa variabel yang memiliki nilai t-statistik diatas 1,69 yaitu variabel kinerja pemda dengan implimentasi e-goverment, sedangkan variabel karakteristik pemda dan karakteistik demografi dengan implimentasi e-goverment memiliki nilai $\mathrm{T}$ statistik dibawah 1,69 yaitu 0,520 dan 1,098 yang artinya karakteristik pemda dan karakteristik demografi tidak memiliki pengaruh terhadap implimentasi $e$ government.

\section{Pembahasan Hasil Pengujian Hipotesis \\ Pengaruh Kinerja Pemda Terhadap implimentasi E-goverment}

Berdasarkan hasil pengujian hipotesis menunjukkan bahwa kinerja pemda berpengaruh signifikan terhadap implementasi e-goverment. Hal ini dapat dilihat dari nilai t statistik di atas 1,69 (t tabel 5\%) yakni sebesar 1,783. Hal ini disebabkan karena kinerja pemda mempunyai kriteria keberhasilan yang telah ditetapkan. Kriteria keberhasilan ini berupa tujuantujuan atau target-target tertentu yang hendak dicapai. Tanpa ada tujuan atau target, kinerja seseorang atau organisasi tidak mungkin dapat diketahui karena tidak ada tolak ukurnya (Mahsun dkk, 2012). Semakin besarnya ukuran pemda dan DAU yang diterima maka kinerja yang ditunjukkan semakin bagus. Kim (2007) menyatakan bahwa kinerja $e$ government ditentukan oleh kesejahteraan ekonomi, pendidikan, urbanisasi, kebebasan rakyat, efektivitas pemerintahan, dan interaksi antara penggunaan internet dan kesejahteraan ekonomi Hal ini dapat 
diartikan bahwa jika kesejahteraan ekonomi daerah tinggi, maka pemerintah daerah mempunyai biaya yang cukup untuk melayani masyarakatnya melalui implementasi e-government, karena implementasi e-government diharapkan untuk menyediakan pelayanan kepada masyarakat yang membutuhkan biaya besar.

UU Nomor 33 Tahun 2004 mendefinisikan Dana Alokasi Umum adalah dana yang dialokasikan kepada pemerintah daerah yang bertujuan pemerataan kemampuan keuangan antar daerah. Dana alokasi umum bersifat "Block Grant" yang artinya kepala daerah dapat menggunakan dana alokasi umum sesuai kebutuhan suatu daerah yang diprioritaskan secara bertanggung jawab. Robbin dan Austin (1986) menyatakan bahwa besarnya dana alokasi umum yang diterima menggambarkan tingkat ketergantungan yang dimiliki suatu pemerintah daerah. Liestiani (2008) mengungkapkan bahwa pemerintah yang memiliki tingkat ketergantungan yang tinggi memiliki tekanan dari pemerintah pusat untuk mengungkapkan informasi keuangan daerah lebih lengkap.

Hal ini sejalan dengan agency theory, dimana kewajiban pemegang amanah (pemerintah) untuk memberikan pertanggungjawaban, menyajikan, melaporkan, dan mengungkapkan segala aktivitas dan kegiatan yang menjadi tanggungjawabnya kepada pihak pemberi amanah (masyarakat) yang memiliki hak untuk meminta pertanggungjawaban tersebut. Pendapat Mardiasmo mengenai akuntabilitas tersebut mengandung arti bahwa terdapat hubungan keagenan antara masyarakat sebagai prinsipal dan pemerintah sebagai agen. Dalam Teori keagenan, pemerintah daerah sebagai agen bagi masyarakat (prinsipal) akan bertindak dengan penuh kesadaran bagi kepentingan mereka sendiri serta memandang bahwa pemerintah daerah tidak dapat dipercaya untuk bertindak dengan sebaik-baiknya bagi kepentingan masyarakat. Teori ini berpendapat bahwa banyak terjadi information asymmetri antara pihak agen (pemerintah) dengan yang mempunyai akses langsung terhadap informasi dengan pihak prinsipal (masyarakat). Oleh karena itu, mengingat pentingnya akuntabilitas terhadap publik tersebut, perlu dilakukan revitalisasi e-government yang dapat meningkatkan akuntabilitas dan transparansi kinerja pemerintah demi kepentingan kesejahteraan masyarakat luas.

\section{Pengaruh Karakterisitik Pemda Terhadap implementasi E- goverment}

Berdasarkan hasil pengujian hipotesis menunjukkan bahwa konstruk karakteristik pemda tidak berpengaruh terhadap implementasi $e$ goverment. Hal ini dapat terlihat dari nilai t statistik di bawah 1,69 (t tabel $5 \%$ ) yakni sebesar 0,520 . Besar kecilnya populasi masyarakat di suatu daerah mempengaruhi berhasil atau tidaknya implementasi e-Government. Idealnya semakin besar populasi, maka akan semakin besar tekanan yang 
ditujukan terhadap pemerintah akan perwujudan akuntabilitas terhadap publik. Sehingga kemungkinan berhasilnya implementasi e-Government akan lebih besar. Tetapi provinsi yang diteliti banyaknya penduduk salah satunya banyak juga pengangguran. Banyaknya pengangguran tidak berpengaruh terhadap implementasi e-government.

Hal ini tidak sejalan dengan agency theory, dimana kewajiban pemegang amanah (pemerintah) untuk memberikan pertanggungjawaban, menyajikan, melaporkan, dan mengungkapkan segala aktivitas dan kegiatan yang menjadi tanggung jawabnya kepada pihak pemberi amanah (masyarakat) yang memiliki hak untuk meminta pertanggungjawaban tersebut. Dalam Teori keagenan, pemerintah daerah sebagai agen bagi masyarakat (prinsipal) akan bertindak dengan penuh kesadaran bagi kepentingan mereka sendiri serta memandang bahwa pemerintah daerah tidak dapat dipercaya untuk bertindak dengan sebaik-baiknya bagi kepentingan masyarakat. Teori ini berpendapat bahwa banyak terjadi information asymmetri antara pihak agen (pemerintah) dengan yang mempunyai akses langsung terhadap informasi dengan pihak prinsipal (masyarakat). Oleh karena itu, mengingat pentingnya akuntabilitas terhadap publik tersebut, perlu dilakukan revitalisasi e-government yang dapat meningkatkan akuntabilitas dan transparansi kinerja pemerintah demi kepentingan kesejahteraan masyarakat luas.

\section{Pengaruh Karakteristik Domestik Terhadap Implementasi E- Goverment}

Berdasarkan hasil pengujian hipotesis menunjukkan bahwa konstruk karakteristik demografi tidak berpengaruh terhadap implementasi egoverment. Hal ini dapat terlihat dari nilai t statistik di bawah 1,69 (t tabel $5 \%$ ) yakni sebesar 1,098. Pendapatan regional perkapita menggambarkan rata-rata pendapatan yang diterima penduduk suatu wilayah pada tahun tertentu. Pendapatan regional perkapita tercermin dalam PDRB (Produk Domestik Regional Bruto). PDRB merupakan indikator untuk mengatur sampai sejauh mana keberhasilan pemerintah dalam memanfaatkan sumber daya yang ada dan dapat digunakan sebagai perencanaan dan pengambilan keputusan. (Sumber: www.bi.go.id) . Oleh karena itu, semakin besar pendapatan perkapita maka semakin tinggi kebutuhan suatu masyarakat akan akuntabilitas pada laporan keuangan. Sedangkan di implementasi e-government lebih banyak mengungkapkan dalam hal non keuangan. Jadi walaupun tinggi pendapatan perkapita tetap tidak berpengaruh terhadap implementasi e-government.

Hal ini tidak sejalan dengan agency theory, dimana kewajiban pemegang amanah (pemerintah) untuk memberikan pertanggungjawaban, menyajikan, melaporkan, dan mengungkapkan segala aktivitas dan kegiatan yang menjadi tanggungjawabnya kepada pihak pemberi amanah 
(masyarakat) yang memiliki hak untuk meminta pertanggungjawaban tersebut. Dalam Teori keagenan, pemerintah daerah sebagai agen bagi masyarakat (prinsipal) akan bertindak dengan penuh kesadaran bagi kepentingan mereka sendiri serta memandang bahwa pemerintah daerah tidak dapat dipercaya untuk bertindak dengan sebaik-baiknya bagi kepentingan masyarakat. Teori ini berpendapat bahwa banyak terjadi information asymmetri antara pihak agen (pemerintah) dengan yang mempunyai akses langsung terhadap informasi dengan pihak prinsipal (masyarakat). Oleh karena itu, mengingat pentingnya akuntabilitas terhadap publik tersebut, perlu dilakukan revitalisasi e-government yang dapat meningkatkan akuntabilitas dan transparansi kinerja pemerintah demi kepentingan kesejahteraan masyarakat luas.

\section{PENUTUP}

\section{Kesimpulan}

1) Kinerja pemda berpengaruh terhadap implementasi e-goverment dikarenakan semakin besar ukuran pemda dan tinggi DAUnya sebuah pemda maka tanggung jawab untuk mengungkapkan informasi kepada masyarakatnya akan tinggi, dengan adanya implementasi $e$ government diharapkan untuk menyediakan pelayanan kepada masyarakat yang membutuhkan biaya besar. Kepala daerah dapat menggunakan dana alokasi umum sesuai kebutuhan suatu daerah yang diprioritaskan secara bertanggung jawab. Besarnya dana alokasi umum yang diterima menggambarkan tingkat ketergantungan yang dimiliki suatu pemerintah daerah. Pemerintah yang memiliki tingkat ketergantungan yang tinggi memiliki tekanan dari pemerintah pusat untuk mengungkapkan informasi keuangan daerah lebih lengkap.

2) Karakteristik pemda tidak berpengaruh terhadap implementasi $e$ government, idealnya semakin besar populasi, maka akan semakin besar tekanan yang ditujukan terhadap pemerintah akan perwujudan akuntabilitas terhadap publik. Sehingga kemungkinan berhasilnya implementasi e-Government akan lebih besar. Tetapi provinsi yang diteliti banyaknya penduduk salah satunya banyak juga pengangguran. Banyaknya pengangguran tidak berpengaruh terhadap implementasi egovernment.

3) Karakteristik pemda tidak berpengaruh terhadap implementasi $e$ government, semakin besar pendapatan perkapita maka semakin tinggi kebutuhan suatu masyarakat akan akuntabilitas pada laporan keuangan. Sedangkan di implementasi e-government lebih banyak mengungkapkan dalam hal non keuangan. Jadi walaupun tinggi pendapatan perkapita tetap tidak berpengaruh terhadap implementasi e-government. 


\section{Keterbatasan dan Saran}

1) Pada penelitian ini memberikan informasi bahwa menunjukkan nilai $R$ Square untuk implementasi e-goverment sebesar 0,249 yang dapat diinterpretasikan bahwa implementasi e-goverment dapat dijelaskan oleh variabel konstruk karakteristik demografi, karakteristik pemda, dan kinerja pemda sebesar 24,9\%, sedangkan sisanya 75,1\% dijelaskan oleh variabel lain diluar yang diteliti seperti factor utang, jumlah dewan, tingkat pendidikan, kompleksitas pemerintah dan lainnya. Sehingga diharapkan kedepannya perlu adanya penelitian lebih lanjut mengenai implementasi e-goverment.

2) Diharapkan pada penelitian selanjutnya bisa lebih memperluas rentang penelitian seperti pemerintah daerah tingkat II di seluruh Indonesia. Dengan banyaknya sampel akan semakin memperkuat hasil dari penelitian tersebut.

3) Diharapkan pada penelitian selanjutnya akan lebih banyak memuat penelitian terdahulu untuk lebih menguatkan penelitiannya, karena pada penelitian ini menggunakan cukup sedikit penelitian terdahulunya. Sehingga diharapkan pada penelitian selanjutnya dapat lebih banyak penggunaan penelitian terdahulu atas variabel yang digunakan.

\section{DAFTAR PUSTAKA}

Chun et al, 2012. Collaborative E-government. Transforming Government: People, Process and Policy. 6(1) pp.5-12.

Dwei, Sopia. 2013. Faktor-faktor yang mempengaruhi implementasi $e$ government. Skripsi. Universitas Diponegoro. Semarang

Ferdinand, Augusty. 2006. Metode Penelitian Manajemen: Pedoman Penelitian untuk skripsi, Tesis dan Disertai Ilmu Manajemen. Semarang: Universitas Diponegoro.

Ghozali, Imam. 2011. Structural Equation Modeling Metode Alternatif dengan Partial Least Square (PLS). Semarang: Undip.

Haryanto, Sahmuddin, Arifuddin, 2007, Akuntasi Sektor Publik, Semarang, Badan Penerbit UNDIP

https://bpptik.kominfo.go.id/2016/09/09/2190/inilah-peringkat-egovernment-indonesia-berdasarkan-survei-pbb-2016/ : Diakses pada tanggal 12 Maret 2017

Jaya, Dharma; Sisdyaniz, Ardhani. 2014. Pengaruh Pendapatan Asli Daerah, Dana Alokasi Umum, Dan Belanja Modal Pada Kelengkapan Pengungkapan Informasi Keuangan Daerah Melalui Situs Resmi Pemerintah Provinsi. E-Jurnal Akuntansi Universitas Udayana. 9.1 (2014): 162-179

Jogiyanto. 2007. Model Kesuksesan Sistem Teknologi Informasi. Andi. Yogyakarta. 
Kementerian Komunikasi dan Informasi Republik Indonesia. 2003. Cetak Biru (Blueprint) Sistem Aplikasi e-Government bagi Lembaga Pemerintah Daerah. Jakarta: Pemerintah Indonesia.

Kementerian Komunikasi dan Informasi Republik Indonesia. 2003. Panduan Penyusunan Rencana Induk Pengembangan e-Government Lembaga. Jakarta: Pemerintah Indonesia.

Lupia, Arthur \& Mathew McCubbins. 2000. Representation or abdication? How citizens use institutions to help delegation succeed. European Journal of Political Research 37: 291-307

Mardiasmo. 2002. Akuntansi Sektor Publik. Penerbit Andi. Yogyakarta.

Martani, Dwi dan Annisa Liestiani. 2010. Disclosure of Local Government Financial Statement in Indonesia. University of Indonesia. Depok

Martani, Dwi; Rahim. 2013. Analisis Pengaruh Tingkat Akses Internet, Kompetisi Politik, Opini Audit, Karakteristik Pemda, Dan Karakteristik Demografi Terhadap Pengungkapan Informasi Keuangan Dan NonKeuangan Website Pemerintah Daerah. Universitas Indonesia. Jakarta

Napitupulu, Darmawan. 2015. Kajian Faktor Sukses Implementasi EGovernment Studi Kasus: Pemerintah Kota Bogor. Jurnal Sistem Informasi, Volume 5, Nomor 3, Maret 2015, 229-236

Rudiyanto, Purwanugraha. 2015. Pengaruh kinerja dan karakteristik pemda terhadap pengungkapan pada website pemda. Program Studi Akuntansi, Fakultas Ekonomi, Universitas Atma Jaya Yogyakarta

Sari, Rora Puspita. 2010. Pengaruh Kinerja Pemerintah Daerah terhadap Tingkat Pengungkapan Sukarela Pemerintah Daerah di Indonesia pada Situs Pemerintah Daerah Tahun 2010. Depok: Skripsi Departemen Akuntansi, Fakultas Ekonomi, Universitas Indonesia.

Sipahutar dan Sutarya. 2016. Faktor-faktor penentu implementasi egovernment pemerintah daerah di Indonesia. Simposium Nasional Akuntansi IX. Lampung

Sugiyono. 2011. Metode Penelitian Kuantitatif Kualitatif dan R\&D. Bandung: Alfabeta.

www.bpsntb.go.id diakses pada tanggal 20 Maret 2018

www.bi.go.id, diakses pada tanggal 15 Juli 2018 